\title{
Effective HAART reduces the incidence of high grade cervical neoplasia in HIV positive women
}

\author{
Deborah Morris-Harris ${ }^{1 *}$, Charmaine Miller-Spencer ${ }^{1}$, Clara Jones ${ }^{2}$, Song Zhang $^{3}$, James Luby ${ }^{3}$ \\ From 17th International Symposium on HIV and Emerging Infectious Diseases (ISHEID) \\ Marseille, France. 23-25 May 2012
}

\section{Introduction}

Highly active antiretroviral therapy (HAART) has been shown to restore immunity and reduce the burden of Human Immunodeficiency Virus (HIV) in patients with HIV infections. Co-infection with HIV and the Human Papilloma Virus has been estimated to be as high as $51 \%$ in HIV positive women. Recently effective HAART has been shown to reduce the prevalence of HPV and intraepithelial lesions on Papanicolaou (pap) smear. It is unclear if HIV viral suppression can reduce the incidence of high grade cervical neoplasia .

\section{Materials and methods}

A retrospective cohort of 1090 women, in care from 2005 through 2008, had 389 referrals to colposcopy clinic. 142 women mean age of 31.2 (range 17-54); 66.2\% Non -Hispanic black,9.9\% Non- Hispanic white, and 23.9\% Hispanic with HIV, median baseline CD4 283 (IQR 87.75-508) had a colposcopy and a second procedure, either colposcopy or excisional biopsy after a baseline abnormal Pap smear. Follow-up biopsies were performed with a median of 11.9 months (IQR 4.4-22.5) There were no significant baseline differences in clinical or demographic parameters between patients who were suppressed with VL.

\section{Results}

Of 125 cases in which HAART was started before the first colpsocopy; 26 had a normal colposcopy and 48 had CIN1. From the normal and low grade group, 19 women developed high grade CIN (7, suppressed and 12, not suppressed.) Effective HAART reduced the risk of CIN2-CIS on a second biopsy by $83.2 \%$ (AHR 0.168; C.I. $=0.057-.498 ; \mathrm{p}<0.001)$ adjusted for age at

\footnotetext{
* Correspondence: beekin@aol.com

${ }^{1}$ Parkland Health and Hospital System, HIV Services, Dallas, Texas, USA

Full list of author information is available at the end of the article
}

diagnosis, race, smoking and baseline CD4. Higher baseline CD4 was associated with a reduced risk of high grade neoplasia (AHR=0.996; C.I. 0.993-0.999; p

\section{Conclusions}

Reducing HIV viral load and preserving CD4 cells early in the course of HIV and HPV co-infection decreases the incidence of high grade cervical neoplasia.

\section{Author details}

'Parkland Health and Hospital System, HIV Services, Dallas, Texas, USA. ${ }^{2}$ Tufts University School of Medicine, Boston, Massachusetts, USA. ${ }^{3}$ University of Texas Southwestern Medical School, Dallas, Texas, USA.

Published: 25 May 2012

\section{doi:10.1186/1742-4690-9-S1-P131}

Cite this article as: Morris-Harris et al.: Effective HAART reduces the incidence of high grade cervical neoplasia in HIV positive women. Retrovirology 2012 9(Suppl 1):P131.
Submit your next manuscript to BioMed Central and take full advantage of:

- Convenient online submission

- Thorough peer review

- No space constraints or color figure charges

- Immediate publication on acceptance

- Inclusion in PubMed, CAS, Scopus and Google Scholar

- Research which is freely available for redistribution
C Biomed Central

\section{Biomed Central}

